Review

\title{
Bone Marrow-derived Vascular Cells in Response to Injury
}

\author{
Koutaro Yokote, Ayako Take, Chiaki Nakaseko, Kazuki Kobayashi, Masaki Fujimoto, \\ Harukiyo Kawamura, Yoshiro Maezawa, Miki Nishimura, Seijiro Mori, \\ and Yasushi Saito
}

Department of Clinical Cell Biology and Medicine, Chiba University Graduate School of Medicine, Chiba, Japan.

\begin{abstract}
Intimal hyperplasia is a key lesion for various vascular disorders such as atherosclerosis, postangioplasty restenosis and transplant arteriopathy. It has widely been accepted that intimal smooth muscle cells (SMC) originate from the medial layer in the same artery. However, recent studies suggest that bone marrow can also provide circulating progenitors for vascular SMC. Bone marrow-derived SMC participate in neointimal formation in animal models of allotransplantation, severe mechanical injury and hyperlipidemia-induced atherosclerosis. In human, transplantation arteriopathy also seems to involve circulating SMC, but their role in atherosclerosis and restenosis remains to be elucidated. Mobilization, differentiation and proliferation steps of SMC progenitors will provide promising targets for novel therapeutic approaches against proliferative vascular diseases. J Atheroscler Thromb, 2003; 10: 205-210.
\end{abstract}

Key words: Response to injury, Smooth muscle cells, Progenitor, Bone marrow

\section{Introduction}

Neointimal hyperplasia is a common feature of various cardiovascular disease such as atherosclerosis, postangioplasty restenosis, transplant arteriopathy and pulmonary hypertension. Neointima typically consists of smooth muscle cells (SMC) and extracellularly deposited matrix. In atherosclerotic vascular lesions, the intimal structure is even more complicated by the involvement of monocyte-derived foamy macrophages and $T$ lymphocytes which derive from blood stream (1).

Intimal and medial SMC differ from each other in several aspects, e.g. cytoskeletal characters, responses to growth factors/cytokines and their ability to deposit matrix. It has widely been accepted, as proposed by Russel Ross and others in the "Response to Injury" hypothesis,

Address for correspondence: Koutaro Yokote, Department of Clinical Cell Biology and Medicine, Chiba University Graduate School of Medicine, 1-8-1 Inohana, Chuo-ku, Chiba 260-8670, Japan.

E-mail: kyokote-cib@umin.ac.jp

Received February 12, 2003.

Accepted for publication February 19, 2003. that the intimal SMC originate from the medial layer of the artery (2). According to their theory, vascular injury leads to endothelial dysfunction and subsequent upregulation of local growth factors and cytokines. These changes in turn prompts transition of medial contractile SMC into more synthetic phenotype, whereby they migrate into the intimal layer and proliferate.

Some groups proposed that not only SMC but other type of mesenchymal cells like adventitial fibroblasts might also be involved in formation of neointima $(3,4)$. More recently, bone marrow has emerged as a new source of intimal SMC or SMC-like cells (5-7). Precise understanding on the origin of neointimal SMC may provide a clue to develop an ideal therapeutical approach towards vascular diseases. We will overview the pathological significance of bone marrow-derived vascular cells with special emphasis on SMC in this review article.

\section{Where Do Neointimal SMC Come From?}

Although extensive researches have been carried out to clarify the cause of intimal proliferative vascular disorders, the origin of intimal SMC remains controversial. 


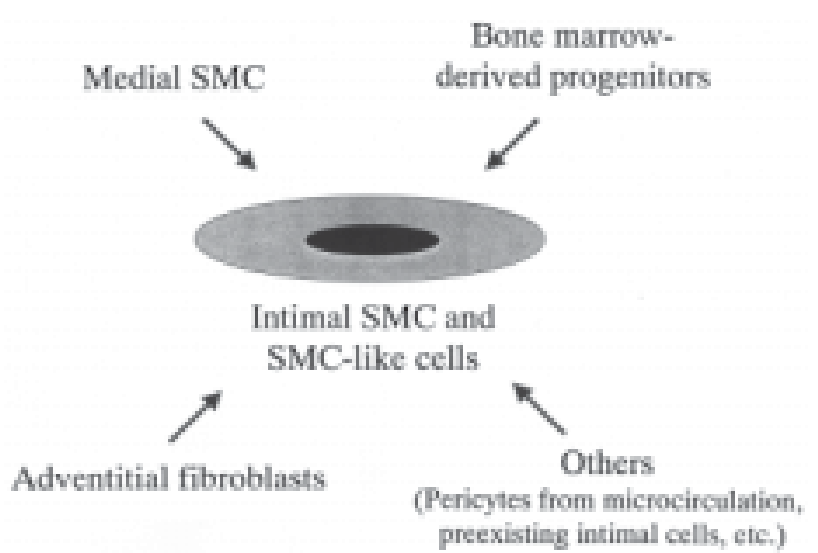

Fig. 1. Possible origin of intimal SMC and SMC-like cells. SMC; smooth muslce cells

Figure 1 shows currently presented theories concerning the source of intimal SMC. Change in medial SMC from contractile to synthetic phenotype followed by migration into the intima is so far the most widely accepted mechanism of neointimal formation $(2,8)$. In addition, Shi et al. suggested the possibility that adventitial fibroblasts migrate towards the lumen, differentiate into myofibroblasts and participate in neointimal formation (3). Other proposed cause of neointimal hyperplasia include expansion of preexisting intimal cells and circulating pericytes those derive from microvessels (3). Recently, several groups independently discovered that bone marrow-derived cells with some features of SMC accumulated in neointima in animal models of transplantation arteriopathy or severe vascular injury (5-7). It has long been believed that the only source of endothelial cells and SMC in adults is the blood vessel wall. However, since Asahara et al. established the concept of "circulating endothelial progenitors" which contribute to vasculogenesis in adult tissues under both physiological and pathological conditions, the bone marrow cells have been highlighted for their remarkable plasticity (9). The circulating SMC progenitors can be a new therapeutic target for various proliferative vascular diseases. On the other hand, there also are results indicating that bone marrow is unlikely to be the source of neointimal SMC $(10,11)$. Pathological relevance of bone marrow-derived SMC will be discussed in the further sections.

\section{Bone Marrow-derived SMC in Response to Vascular Injury}

\section{Transplant arteriopathy}

Table 1 summarizes published studies in which contribution of bone marrow as a source of intimal SMC was examined. So far, at least 4 papers have been presented by independent research groups investigating the cell origin of intimal SMC in rodent aortic allograft models
$(5-7,12)$. According to their results, between 10 to $70 \%$ of the neointimal SMC were shown to originate from the recipient tissue. Shimizu et al. performed allogenic aortic transplantation from BALB/c (B/c) mice into C57BL/6 (B6) ROSA26 $\beta$-galactosidase (LacZ) transgenic mice which ubiquitously express LacZ (LacZ mice) (7). The graft after 8 weeks showed marked neointimal hyperplasia mostly composed of the cells double positive for X-gal and $\alpha$-smooth muscle actin ( $\alpha$-SMA), which are the markers of the recipient cells and SMC, respectively. When $\mathrm{B} / \mathrm{c}$ aortic transplantation was performed into irradiated wildtype $\mathrm{B} 6$ recipients of $\mathrm{B} 6 \mathrm{LacZ}$ mice-bone marrow cells, approximately $10.8 \%$ of $\alpha$-SMA-expressing intimal cells also stained positive for $\mathrm{X}$-gal. The results suggested that at least part of the intimal SMC-like population is accounted for by circulating bone marrow-derived cells. However, the origin of other recipient-derived SMC-like cells was not determined in the study.

Hu et al. also showed that the majority of intimal SMC in allogenic transplant arteriopathy and transplant atherosclerosis originates from recipients, but carefully disproved that bone marrow served as the source (11). They utilized transgenic mice expressing LacZ only in SMC (SM-LacZ). When B/c aorta was transplanted to irradiated wildtype B6 recipients of B6 SM-LacZ bone marrow, no LacZ activity was found in the graft intima indicating that the bone marrow cells were unlikely to be a source of SMC in allografts. Supported by previous reports and their own observation, they claimed that Xgal/ $\alpha$-SMA double positive cells observed by other groups could be artificial, since those cells might have been adjascent regions of SMC and leukocytes that were too close to be separately recognized in the sections. This is in accord with a study previously performed by $\mathrm{Li}$ et al. (10) in which they used in situ hybridization of sexchromosome markers to identify the cell origin. In their study, female to male aortic allograft abundantly contained Y-chromosome-positive or recipient-derived intimal cell which co-labeled for $\alpha$-SMA by immunostaining. However, in female-to-female allografts in recipients with male bone marrow showed limited number of intimal $Y$ chromosome positive cells, and none of these clearly colabeled for $\alpha$-SMA. The results suggested that the SMC were indeed of recipient origin, but the bone marrow was unlikely to be their source. Moreover, these cells declined in number throughout the time after transplantation consistent with graft-infiltrating inflammatory cells.

A few reports referred to pathological significance of circulating or bone marrow-derived SMC progenitors in development of organ transplant arteriopathy other than arterial grafts. Saiura et al. elegantly showed the involvement of bone marrow-derived $\alpha$-SMA positive cells in coronary neointimal hyperplasia by performing heterotopic cardiac transplantation between the wildtype and LacZ mice (6). It is to be noted that the cells of bone 
Table 1. Summary of previous studies those examined the contribution of bone marrow as a source of intimal SMC.

\begin{tabular}{|c|c|c|c|c|c|c|}
\hline Experimental design & Species & $\begin{array}{l}\text { Method to } \\
\text { determine the } \\
\text { cell origin }\end{array}$ & $\begin{array}{c}\text { SMC } \\
\text { determination }\end{array}$ & Origin of Intimal SMC & BM-derived SMC & Publication \\
\hline \multicolumn{7}{|l|}{ Transplantation arteriopathy } \\
\hline Aortic allotransplantation & mice & Y-Chr/ISH & SMA staining & Adjacent recipient aorta & Few if any & $\begin{array}{l}\text { Li et al. } 2001 \\
\quad(10)\end{array}$ \\
\hline $\begin{array}{l}\text { Aortic allotransplantation with } \\
\text { or without hyperlipidemia }\end{array}$ & mice & $\begin{array}{l}\text { ROSA26 mice } \\
\text { with X-gal } \\
\text { staining }\end{array}$ & SMA staining & Recipient cells & $\begin{array}{l}10.8 \% \text { of intimal } \\
\text { SMC }\end{array}$ & $\begin{array}{l}\text { Shimizu et al. } \\
2001(7)\end{array}$ \\
\hline Aortic allotransplantation & mice & $\begin{array}{l}\text { ROSA26 mice } \\
\text { with X-gal } \\
\text { staining }\end{array}$ & $\begin{array}{l}\text { SM-LacZ } \\
\text { transgenic, } \\
\text { X-gal staining }\end{array}$ & $\begin{array}{l}\text { Recipient tissue but not } \\
\text { from bone marrow }\end{array}$ & Not detected & $\begin{array}{l}\text { Hu et al. } 2002 \\
\quad(11)\end{array}$ \\
\hline Aortic allotransplantation & rat & $\begin{array}{c}\text { Y-Chr/Real- } \\
\text { time PCR }\end{array}$ & SMA staining & $\begin{array}{l}\text { Recipient cells involved } \\
(70 \%)\end{array}$ & Present & $\begin{array}{l}\text { Religa et al. } \\
2002(12)\end{array}$ \\
\hline Cardiac allotransplantation & mice & $\begin{array}{l}\text { ROSA26 mice } \\
\text { with X-gal } \\
\text { staining }\end{array}$ & SMA staining & $\begin{array}{l}\text { Recipient cells involved } \\
(86.2 \%)\end{array}$ & $\begin{array}{l}\text { Majority of } \\
\text { intimal SMC }\end{array}$ & $\begin{array}{l}\text { Saiura et al. } \\
2001(6)\end{array}$ \\
\hline Cardiac allotransplantation & human & Sex-Chr/ISH & SMA staining & $\begin{array}{l}\text { Recipient-derived SMC } \\
\text { present }\end{array}$ & Present & $\begin{array}{l}\text { Quaini et al. } \\
2002(18)\end{array}$ \\
\hline Renal allotransplantation & human & Y-Chr/ISH & SMA staining & $\begin{array}{l}\text { Recipient cells involved } \\
(30 \%)\end{array}$ & Present & $\begin{array}{c}\text { Grimm et al. } \\
2001(17)\end{array}$ \\
\hline \multicolumn{7}{|l|}{$\underline{\text { Restenosis and atherosclerosis }}$} \\
\hline $\begin{array}{l}\text { Congenic BMT followed by } \\
\text { arterial injury }\end{array}$ & mice & $\mathrm{Y}-\mathrm{Chr} / \mathrm{ISH}$ & SMA staining & $\begin{array}{l}\text { Bone marrow cells } \\
\text { involved }(56 \%)\end{array}$ & $\begin{array}{l}\text { Majority of intimal } \\
\text { SMC }\end{array}$ & $\begin{array}{l}\text { Han et al. } \\
2001 \text { (5) }\end{array}$ \\
\hline $\begin{array}{l}\text { Isogenic BMT followed by } \\
\text { arterial injury or } \\
\text { hyperlipidemia }\end{array}$ & mice & $\begin{array}{l}\text { GFP, ROSA26 } \\
\text { with X-gal } \\
\text { staining }\end{array}$ & SMA staining & $\begin{array}{l}\text { Bone marrow cells } \\
\text { involved }(60 \%)\end{array}$ & $\begin{array}{l}\text { Majority of intimal } \\
\text { SMC }\end{array}$ & $\begin{array}{l}\text { Sata et al. } \\
2002(14)\end{array}$ \\
\hline $\begin{array}{l}\text { Vein isograft with } \\
\text { hyperlipidemia }\end{array}$ & mice & $\begin{array}{l}\text { ROSA26 } \\
\text { staining with } \\
\text { X-gal staining, } \\
\text { and Y-Chr/ISH }\end{array}$ & $\begin{array}{l}\text { SM-LacZ } \\
\text { transgenic, } \\
\text { X-gal staining }\end{array}$ & $\begin{array}{l}\text { Both donor }(60 \%) \text { and } \\
\text { host }(40 \%) \text { cells involved, } \\
\text { but not from bone marrow }\end{array}$ & Not detected & $\begin{array}{l}\text { Hu et al. } 2002 \\
\text { (16) }\end{array}$ \\
\hline
\end{tabular}

SMC; smooth muslce cells, SMA; $\alpha$-smooth muscle action, Y-Chr; Y-chromosome, Sex-Chr; Sex-chromosome, ISH; in situ hybridization, ROSA26; transgenic ubiquitously expressing $\beta$-gal

marrow origin accounted for up to $86 \%$ of the intimal cells in their study. Vascular bed-specific differences between aorta and coronary artery may in part explain the degree of bone marrow cell contribution in the intimal hyperplasia.

\section{Postangioplasty restenosis}

Atherosclerosis and postangioplasty restenosis are other important vascular disorders also characterized by intimal hyperplasia. They affect large number of population especially in the Western countries and in Japan (13). Several research groups have investigated whether vascular smooth muscle cells might derive from bone marrow in animal models of postangioplasty restenosis.

Han et al. performed congenic male-to-female bone marrow transplantation followed by arterial injury, and examined localization of donor cells using $\mathrm{Y}$-chromosome in situ hybridization in mice (5). They showed that bone marrow-derived cells are recruited in vascular healing as a complementary source of SM-like cells when the me- dia is severely damaged and few resident SMC are available for effective repairment. Molecular mechanisms by which these cells are mobilized and led to injured vessels is yet to be discovered.

Sata et al. also examined whether bone marrow serves as the source for arterial SMC upon mechanical vascular injury (14). They wire-injured the femoral artery of irradiated B6 mice to which LacZ transgenic bone marrow was transplanted. The procedure resulted in neointimal hyperplasia, and more than $60 \%$ and $40 \%$ of intimal and medial cells, respectively, turned out to be LacZ positive, suggestive of the bone marrow origin. Moreover, they showed that $\mathrm{C}-\mathrm{Kit}^{+} \mathrm{Sca}-\mathrm{1}^{+} \mathrm{Lin}-{ }^{-}$hematopoietic stem cells (HSC) purified from GFP transgenic mice gave rise to $\alpha$-SMA-expressing cells in the injured arteries in vivo. They also described that HSC differentiated into $\alpha$-SMApositive SMC-like cells by co-incubation with cultured rat SMC in vitro. The possibility of HSC fusion with SMC in vitro rather than transdifferentiation of $\mathrm{HSC}$ as suggested by Terada et al. (15) was not excluded in the study. 
Endothelial progenitors are also implicated in neointimal formation in response to injury. Werner et al. described that bone marrow-derived endothelial progenitors participated in reendothelialization of injured carotid artery in mice. Interestingly, statin increased the circulating pool of endothelial progenitor cells and facilitated arrival of these cells to injured vessel wall. As the result, the lesion showed enhanced reendothelialization and decreased neointimal formation. Long-term fate of these cells and their interaction with SMC progenitors remain to be investigated.

\section{Atherosclerosis}

Atherosclerotic vascular lesion induced by hyperlipidemia is characterized by lipid rich plaque of foamy macrophages covered by so-called fibrous cap composed of intimal SMC and extracellular matrix. SMC content in fibrous cap is thought to be an important determinant of plaque stability. Sata et al. examined the aortic wall of hyperlipidemic ApoE knockout mice which bone marrow was reconstituted with the cells from either GFP or LacZ transgenic mice. Surprizingly, approximately 40 to $60 \%$ of $\alpha$-SMA-positive cells in atherosclerotic plaques showed the bone marrow markers.

Hu et al. examined the origin of SMC in atherosclerotic plaque developed in isogenic vein graft (16). They grafted vena cava segments to carotid arteries between four types of transgenic mice, including transgenic LacZ mice, SM-LacZ mice expressing LacZ only in the vascular SMC, SM-LacZ/apoE(-/-) mice and the wild-type mice. LacZpositive cells were observed in neointimal and atherosclerotic lesions of all vein segments grafted between LacZ transgenic and wild-type mice. Double staining for LacZ and cell nuclei revealed that about $40 \%$ of SMCs originated from hosts and $60 \%$ from the donor vessel. However, the host cells were unlikely to be of bone marrow origin since the vein graft did not contain X-galstained cells when transplanted to "chimeric" mice which bone marrow was reconstituted with SM-LacZ bone marrow cells.

It remains to be elucidated why the bone marrow cells contributed to SMC formation in arterial lesions but not in vein graft atherosclerosis.

\section{Bone Marrow-derived SMC in Human Vascular Lesions}

Are the bone marrow-derived progenitor cells also involved in SMC formation in human vascular disease just as described in the animal models?

It was reported that in female-to-male renal transplantation cases with the signs of chronic rejection, 34\% of neointimal smooth muscle cells in the graft specimen expressed $\mathrm{Y}$-chromosomomal signal, a marker for the recipient cells (17). Therefore, it was suggested that circulating mesenchymal precursor cells exist and are involved in arterial neointimal formation.

Quaini et al. described that in cardiac transplant from female donor to male recipient, $50 \%$ of coronary arterioles contained Y-chromosome-positive "recipient" cells (18). Among such vessels harboring recipient cells, 31 to $75 \%$ of the vascular smooth muscle cells showed $Y$-chromosome in their nuclei. Interestingly, the highest levels of chimerism, i.e. co-existence of donor and recipient cells, in the arterioles were found between 4 and 28 days of transplantation. The level of chimerism declined afterwards suggesting that the contribution of circulating precursors to vascular SMC occur most prominently in the early stage after transplantation.

In order to investigate the origin of human vascular SMC in the vessel wall, we examined the coronary artery autopsy specimens of two individuals who had undergone allogenic bone marrow transplantation (Table 2) (19). A patient was 40-year-old female who was transplanted a brother's bone marrow 10 years earlier. She had diabetes mellitus and her coronary artery showed marked dif-

Table 2. Examination of vascular SMC origin in cases of allogenic bone marrow transplantation.

\begin{tabular}{|c|c|c|c|c|c|c|c|c|}
\hline $\begin{array}{l}\text { Patient } \\
\text { (bone marrow } \\
\text { recipient) }\end{array}$ & $\begin{array}{l}\text { Background } \\
\text { disease }\end{array}$ & $\begin{array}{l}\text { Donor of } \\
\text { bone } \\
\text { marrow } \\
\text { stem cells }\end{array}$ & $\begin{array}{l}\text { Systemic } \\
\text { inflamma- } \\
\quad \text { ation }\end{array}$ & $\begin{array}{l}\text { Period } \\
\text { after } \\
\text { BMT }\end{array}$ & $\begin{array}{l}\text { Method to } \\
\text { determine } \\
\text { the cell origin }\end{array}$ & $\begin{array}{c}\text { SMC } \\
\text { determination }\end{array}$ & $\begin{array}{l}\text { Bono marrow } \\
\text { replacement }\end{array}$ & Results \\
\hline $\begin{array}{l}50 \text { year-old } \\
\text { female }\end{array}$ & $\begin{array}{l}\text { Acute } \\
\text { myelogenous } \\
\text { leukemia }\end{array}$ & Brother & Absent & 10 years & $\begin{array}{l}\text { in situ hybridi- } \\
\text { zation for } \\
\text { Y-and X- } \\
\text { chromosomes }\end{array}$ & SMA staining & Successful & $\begin{array}{l}\text { Intimal SMC were } \\
\text { negative for bone } \\
\text { marrow cell marker } \\
\text { (Y-chromosome) }\end{array}$ \\
\hline $\begin{array}{l}25 \text { year-old } \\
\text { female }\end{array}$ & $\begin{array}{l}\text { Chronic EB } \\
\text { virus infection } \\
\text { with malignant } \\
\text { lymphoma }\end{array}$ & Sister & Present & 90 days & $\begin{array}{l}\text { Immunohisto- } \\
\text { chemical } \\
\text { staining for } \\
\text { ABO blood } \\
\text { group antigens }\end{array}$ & SMA staining & Successful & $\begin{array}{l}\text { Some medial cells } \\
\text { expressed both } \\
\text { SMA and donor } \\
\text { blood group antigen }\end{array}$ \\
\hline
\end{tabular}

SMC; smooth muslce cells, SMA; $\alpha$-smooth muscle actin, BMT; bone marrow transplantation 
fuse intimal hyperplasia. Leukocytes in the arterial lumen were $\mathrm{Y}$-chromosome-positive as determined by in situ hybridization indicating that the marrow had successfully been replaced with donor cells. However, none of the intimal SMC contained Y-chromosome-positive suggesting that intimal SMC were not of bone marrow origin in this case. On the other hand, examination of the other case, a female with chronic Epstein-Barr virus infection who died 90 days after receiving bone marrow from a sister, implied the presence of bone marrow-derive SMClike cells. The donor blood type was $\mathrm{A}$, and the recipient originally had the blood type of $\mathrm{B}$. When the recipient's coronary artery was immunohistologically stained with a specific antibody against blood type $A$ antigen, a group of cells in the medial layer showed positive signals indicating that they originated from the bone marrow. The cells at least in part showed characteristics of SMC, since they were positive for $\alpha$-SMA but negative for panleukocyte antigen CD45. Pathophysiological significance of the bone marrow-derived SMC-like cells in vascular media but not in intima remains to be elucidated. Systemic inflammation caused by chronic EB infection might have caused of the appearance of bone marrowderived SMC-like cells. Another possibility suggested by ours and Quaini's studies is that circulating SMC precursors appear in vessel wall early after transplantation or injury and fade away as the time goes by.

\section{Conclusion}

Many studies based on animal experiments indicate that a population of bone marrow-derived cells give rise to SMC or SM-like cells and contribute to blood vessel structure in various situations. Unsolved questions include the fate of bone marrow-derived SMC in long-term and whether they have a different role from media-derived SMC. Further characterization of circulating SMC progenitors and identification of the molecular signals which mobilize and recruit these cells to injured vessel may provide a new promising target for proliferative vascular diseases.

It is also interesting to know how these cells are involved in human atherosclerotic and restenotic lesions. Autopsy specimens from organ or bone marrow transplantation cases with advanced atherosclerosis, although such are rare, will be very informative in this aspect.

Acknoledgements: We thank Drs. Kenichi Harigaya and Kazuhiko Azuma for valuable advice and fruitful discussion.

\section{Reference}

(1) Ross R: Atherosclerosis - an inflammatory disease. N Engl J Med 340, 115-126, 1999
( 2 ) Ross R: The pathogenesis of atherosclerosis: a perspective for the 1990s. Nature 362, 801-809, 1993

(3) Shi Y, O'Brien JE, Fard A, Mannion JD, Wang D, and Zalewski A: Advantial myofibroblasts contribute to neointimal formation in injured porcine coronary arteries. Circulation 94, 1655-1664, 1996

(4) Scott NA, Cipolla GD, Ross CE, Dunn B, Martin FH, Simonet $\mathrm{L}$, and Wilcox JN: Identification of a potential role for the adventitia in vascular lesion formation after balloon overstretch injury of porcine coronary arteries. Circulation 93, 2178-2187, 1996

( 5 ) Han $\mathrm{Cl}$, Campbell GR, and Campbell JH: Circulating bone marrow cells can contribute to neointimal formation. J Vasc Res 38, 113-119, 2001

(6) Saiura A, Sata M, Hirata Y, Nagai R, and Makuuchi $\mathrm{M}$ : Circulating smooth muscle progenitor cells contribute to atherosclerosis. Nat Med 7, 382-383, 2001

( 7 ) Shimizu K, Sugiyama S, Aikawa M, Fukumoto Y, Rabkin E, Libby P, and Mitchell RN: Host bone-marrow cells are a source of donor intimal smoothmuscle-like cells in murine aortic transplant arteriopathy. Nat Med 7, 738-741, 2001

( 8 ) Campbell GR, and Campbell JH: The phenotypes of smooth muscle expressed in human atheroma. Ann N Y Acad Sci 598, 143-158, 1990

(9) Asahara T, Murohara T, Sullivan A, Silver M, van der Zee R, Li T, Witzenbichler B, Schatteman G, and Isner JM: Isolation of putative progenitor endothelial cells for angiogenesis. Science 275, 964967, 1997

(10) Li J, Han X, Jiang J, Zhong R, Williams GM, Pickering JG, and Chow LH: Vascular smooth muscle cells of recipient origin mediate intimal expansion after aortic allotransplantation in mice. Am J Pathol 158, 1943-1947, 2001

(11) Hu Y, Davison F, Ludewig B, Erdel M, Mayr M, Url $M$, Dietrich $H$, and Xu Q: Smooth muscle cells in transplant atherosclerotic lesions are originated from recipients, but not bone marrow progenitor cells. Circulation 106, 1834-1839, 2002

(12) Religa $P$, Bojakowski K, Maksymowicz $M$, Bojakowska M, Sirsjo A, Gaciong Z, Olszewski W, Hedin U, and Thyberg J: Smooth-muscle progenitor cells of bone marrow origin contribute to the development of neointimal thickenings in rat aortic allografts and injured rat carotid arteries. Transplantation 74, 1310-1315, 2002

(13) Koizumi J, Shimizu M, Miyamoto S, Origasa $H$, and Mabuchi H: Effect of pravastatin-induced LDL-cholesterol reduction on coronary heart disease and cerebrovascular disease in Japanese: Hokuriku lipid coronary heart disease study-pravastatin atherosclerosis trial (Holicos-PAT). J Atheroscler Thromb 9, 251-259, 2002

(14) Sata M, Saiura A, Kunisato A, Tojo A, Okada S, 
Tokuhisa T, Hirai H, Makuuchi M, Hirata $Y$, and Nagai R: Hematopoietic stem cells differentiate into vascular cells that participate in the pathogenesis of atherosclerosis. Nat Med 8, 403-409, 2002

(15) Terada N, Hamazaki T, Oka M, Hoki M, Mastalerz DM, Nakano Y, Meyer EM, Morel L, Petersen BE, and Scott EW: Bone marrow cells adopt the phenotype of other cells by spontaneous cell fusion. Nature 416, 542-545, 2002

(16) Hu Y, Mayr M, Metzler B, Erdel M, Davison F, and $\mathrm{Xu} \mathrm{Q}$ : Both donor and recipient origins of smooth muscle cells in vein graft atherosclerotic lesions. Circ Res 91, e13-e20, 2002

(17) Grimm PC, Nickerson P, Jeffery J, Savani RC, Gough J, McKenna RM, Stern E, and Rush DN:
Neointimal and tubulointerstitial infiltration by recipient mesenchymal cells in chronic renal-allograft rejection. N Engl J Med 345, 93-97, 2001

(18) Quaini F, Urbanek K, Beltrami AP, Finato N, Beltrami CA, Nadal-Ginard B, Kajstura J, Leri A, and Anversa $\mathrm{P}$ : Chimerism of the transplanted heart. $\mathrm{N}$ Engl $\mathrm{J}$ Med 346, 5-15, 2002

(19) Yokote K, Take A, Kobayashi K, Fujimoto M, Kawamura H, Asaumi S, Mori S, and Saito Y: Identification of the origin of smooth muscle cells in human arteriosclerosis: A study on allogenic bone marrow transplantation recipients. The 12th International Vascular Biology Meeting, Karuizawa, Japan, May12-16, 2002 